\title{
COVID-2019 Vaccine A Scientometric Assessment of Global Publications during 2020
}

\author{
BM Gupta ${ }^{1, *}$, KK Mueen Ahmed ${ }^{2}$ \\ 'Formerly with CSIR-NISTADS, New Delhi, INDIA. \\ ${ }^{2}$ Phcog.Net, St. Thomas Town, Bengaluru, Karnataka, INDIA.
}

\begin{abstract}
Objectives: The study presents a bibliometric assessment of COVID-19 vaccine research publications to understand the current and up-to-date scenario of COVID-19 vaccine research and to track important research players and identify the current areas. Materials and Methods: The global literature on COVID-19 vaccine research published during 2020 were searched in the Scopus database, using the keywords "COVID-19 vaccine" or "Coronavirus 19 vaccine" on 12 September 2020. The 343 global records on COVID-19 vaccine research were obtained which received 2636 citations and were published in 66 countries involving 280 organizations, 259 authors and 191 journals. The publication records obtained were statistically analyzed by using various bibliometric indices: document type, country, collaboration patterns, affiliation, journal name, and citation patterns. Results: Among top 12 countries, USA, U.K and China were the most productive and China, South Korea and USA were the most impactful. Nearly $51 \%$ publications of these top 12 countries were international collaborative. The top most productive organizations were Harvard Medical School, USA (12 papers), University of Washington, Seattle, USA (10 papers) and Fudan University, China (with 12, 10 and 8 papers.
\end{abstract}

Th. top most impactful organizations in terms of citation per paper and relative citation index were Tongji Medical College, China (56.0 and 7.28), Shanghai Medical College, China (33.2 and 4.32) and Chinese Center for Disease Control and Prevention, China (23.5 and 3.06). The most productive journals were Nature, Science and Vaccine (24, 18 and 18 papers each) and the most impactful journals in terms of citations per paper were: Journal of Medical Virology (66.5), Cell (27.2) and New England Journal of Medicine (23.4). Conclusion: This results and findings emerging from the study shed new light on the major progress in the present time on hot topics on COVID-19 vaccine research.

Key words: COVID-19, Vaccine, Global publications, Bibliometrics, Scientometrics.

Correspondence

Dr. BM Gupta,

Formerly with CSIR-NISTADS, New Delhi-11012, INDIA.

Email id: bmgupta1@gmail.com

DOI: 10.5530/jyp.2022.14.8

\section{INTRODUCTION}

In both developed countries and developing world in particular, infectious diseases account for significant worldwide morbidity and mortality. Three infectious diseases among top 10, are the major cause of death globally according to WHO. The burden of infectious diseases is expected to become even greater in the near future in the light of the continuous emergence of infections worldwide. ${ }^{1}$

Within the past two decades, coronavirus infection has broken out recurrently and triggered three widespread epidemics: The severe acute respiratory syndrome (SARS) occurred in China in 2002, the Middle East respiratory syndrome (MERS) emerged in Saudi Arabia in 2012, and now, COVID-19. Pathogens of the above diseases are species in the genus of Betacoronavirus belonging to the family Coronaviridae in the order Nidovirales. ${ }^{2}$

In December 2019, a cluster of viral pneumonia cases of unknown cause, subsequently identified as a novel coronavirus, named as 2019-nCoV or COVID-19 was first reported in Wuhan, China, then spread to all the provinces of China and now has become a global pandemic. ${ }^{3}$ By 16 September 2020, a total of 29,444,198 confirmed cases of COVID-19 in 213 countries, including 931,321 deaths, reported to WHO, which resulted in a great public concern. ${ }^{4}$

The Coronavirus Study Group of the International Committee on Taxonomy of Viruses designated the causative virus as severe acute respiratory syndrome coronavirus 2 (SARS-CoV-2), and the disease, which subsequently spread globally, was named coronavirus disease of 2019 (COVID-2019) by the World Health Organization (WHO). In March 2020, the WHO declared COVID-19 a pandemic. ${ }^{5}$

The clinical symptoms of COVID-19 range from asymptomatic to severe pneumonia and multiple organ failure. The most commonly reported clinical features are fever, cough, breathlessness, myalgia, and fatigue, whereas less common reported clinical features to include diarrhea, headache, conjunctivitis, and runny nose. For a subset of patients, the disease may progress to pneumonia with respiratory failure and even death by the end of the first week. The virus primarily spreads between people through close contact and via respiratory droplets produced from coughs or sneezes]. It mainly enters human cells by binding to the receptor angiotensin converting enzyme- $2 .^{6}$

Consequently, considerable attention has been focused on COVID-19 from medical practitioners/scientists around the world to inhibit/stop the continuous transmission of SARS-CoV-2 and to develop guidelines for the effective treatment of severe cases. As an emerging infectious disease, COVID-19 has garnered great research interest. Medical practitioners/scientists are studying the disease from various scientific and clinical areas, including specialists in infectious diseases, virology and microbiology. ${ }^{7}$

The seriousness of the rapid spread of the SARS-CoV-2 virus has caused people to panic around the world since December 2019. Many uncertainties remain as to certain epidemiological, seroepidemiological, clinical and virological characteristics of the virus and associated clinical 
features. The key task is to explore how to enhance host defenses and/or destroy viral resistance. ${ }^{7}$

The availability of a safe and effective vaccine for COVID-19 is well-recognized as an additional tool to contribute to the control of the pandemic. At the same time, the challenges and efforts needed to rapidly develop, evaluate and produce this at scale are enormous. A global effort is underway round the clock to develop and mass-produce an effective vaccine to counter the new, deadly, and highly infectious coronavirus disease, COVID-19. For developing COVID-19 vaccines, besides substantial efforts made by international agencies, we notice an increasing number of public/private partnership and collaborations taking place between multinational pharmaceutical industry, biotechnology companies with national governments for development of COVID-19 vaccine. ${ }^{8,9}$

In international level, organizations have formed international alliances to expedite vaccine development and prepare for distribution of COVIDVaccines. In this regard, WHO has undertaken s major and extraordinary effort: (i) Harnessing a broad global coalition to develop and evaluate candidate vaccines as quickly and safely as possible; (ii) Mapping candidate vaccines and their progress across the world; (iii) Defining the desired characteristics of safe and effective vaccines to combat the pandemic; (iv) Coordinating clinical trials across the world - giving humanity the best chance of safe and effective vaccines for all. ${ }^{8,9}$

As of September 2020, there were 321 vaccine candidates in development, a 2.5 fold increase since April. However, no candidates have completed clinical trials to prove its safety and efficacy. ${ }^{1}$ In September, some 39 vaccine candidates were in clinical research, 33 in Phase I-II trials, and 6 in Phase II-III trials. ${ }^{10-14}$

In September 2020 the Coalition for Epidemic Preparedness Innovations (CEPI) scientists reported that 9 different technology platforms - with the technology of numerous candidates remaining undefined - were under research and development during 2020 to create an effective vaccine against COVID-19. ${ }^{1}$ According to CEPI, most of the platforms of vaccine candidates in clinical trials as of September are focused on the coronavirus spike protein and its variants as the primary antigen of COVID-19 infection. ${ }^{1}$ DNA or messenger RNA, i.e. DNA vaccines or RNA vaccines, offer considerable promise to alter COVID-19 antigen functions for strong immune responses, and can be rapidly assessed, refined for long-term stability, and prepared for large-scale production capacity. Other platforms being developed in 2020 focus on non-replicating viral vectors, peptides, recombinant proteins, live attenuated viruses, and inactivated viruses. ${ }^{10-14}$

\section{Literature Review}

There is no bibliometric study available so far on assessment of global output on COVID-19 vaccine research both at national and international level. However, quite a good number of studies (published mainly in 2020) are available on bibliometric assessment of Coronavirus research and particularly on COVID-19. In view of shortage of space, we review only few studies here.

Among studies focusing on Cornovirus research, Sri Ram ${ }^{2}$ traced research trends on Coronavirus during 50 years through Scopus database, focusing it analysis on annual growth, productive countries, institutes, authors, journals, highly cited papers, and research focus using keywords. Joshua and Sivaprakasam ${ }^{15}$ analysed research outputs (6424) related to the Coronavirus during January 1968 to March 2020, based on the number of research publications per year, contributing author's clustering pattern, most preferred journals, leading publication, document type, broad research areas, commonly used keywords, the geographical distribution of publications, commonly used languages, and productive institutes.
Among studies focusing on COVID-19, Zyoud and Al-Jabi ${ }^{16}$ used bibliometric analysis to examine global research output $(19,044$ publications from 159 countries and involving 8387 institutions) related to COVID-19, covered in Scopus database during December 2019 up until June 19,2020 ) to determine the top-cited publications, identify current hot topics and the current research priorities. Lou, Tian, Niu, Kang, Lian, Zhangof and Zhang ${ }^{17}$ examined 183 publications (published from 2020 January 14 to 2020 February 29) on Covid-19 originating from 20 different countries and published in in 80 different journals. It identified and analyzed the data included title, corresponding author, language, publication time, publication type and research focus. Jingchun, $\mathrm{Ya}, \mathrm{Na}$, Runjing, Hailiang, Xiaoyan, Guoxiu, Jinhui, Che, Brett D. and Shisan ${ }^{7}$ explored the 143 English and 721 Chinese original research articles and reviews retrieved from both English and Chinese databases in relation to the outcomes of management and characterization of COVID-19 during the early stage of COVID-19 pandemic. Network maps were generated to evaluate the collaborations between different authors, countries/provinces, and institutions. Felice and Polimeni ${ }^{18}$ examined and evaluated the research trends in coronavirus disease (COVID-19) research output (1883 papers published from 94 countries and in 644 journals), using publication outputs, countries, institutions, journals, keywords, funding and citation counts, retrieved from Scopus database.

Gupta, Dhawan, Ahmed and Mamdapur ${ }^{19}$ evaluated global research output (103054 records) on COVID-19 based on quantitative and qualitative indicators. It presents a bibliometric profile of most influential countries, organizations, authors and journals and their collaborative linkages, besides identifying broad subject areas of research, most significant keywords and highly-cited papers related to COVID-19.

In view of this background and due to non-availability of quantitative and qualitative assessment of any COVID-10 vaccine global literature, we decided to undertake a study which aims to examine global scientific output of COVID-19 vaccine research with a view to assess the literature type and source, subject-wise spread and the existing focus and research priorities, identify, significant countries, organizations and authors involved, identify important channels of communications and determine the top-cited publications.

\section{MATERIALS AND METHODS}

Published papers on COVID-19 vaccine research was first identified, retrieved and downloaded on 12.9.2020 in a excel file using a comprehensive search strategy using a Scopus database, considered as the world's largest abstract and citation database of peer-reviewed scientific literature compared with PubMed or Web of Science. The terms used in the search engine of Scopus were either in "Keyword" or "Title" ("COVID 19 Vaccine" or "Coronavirus 2019 Vaccine"). The search yielded 343 global records which were further analyzed to collect data using Excel on the following bibliometric aspects: publication output, document types, country/regions, institute/authors, journals, and citations and international collaboration.

(KEY ("COVID-19 vaccine" or "coronovirus 19 vaccine") or TITLE (“COVID-19 vaccine" or "Coronovirus 19 vaccine"))

\section{ANALYSIS AND RESULTS}

The world publications on Covid-19 vaccine, as indexed in Scopus database (till 12.9.2020) consisted of 343 publications during 2020. These 343 publications have received 2636 citations, averaging to 7.68 citations per paper. Out of 343 publications, 84 papers received funding support from more than 100 national and international funding agencies. The 84 funded papers received 1388 citations, averaging to 16.52 citations per paper. The major funding agencies supporting research in this area 
are: National Institute of Health, USA (17 PAPERS), National Natural Science Foundation of China (11 papers), National Institute of Allergy and Infectious Diseases (10 papers), Bill and Melinda Gates Foundation (7 papers), European Research Council (4 papers), Wellcome Trust (4 papers), Engineering and Physical Science Research Council (3 papers), etc. Of the 343 global publications, 132 were articles, 74 reviews, 63 notes, 43 editorials, 18 letters, 11 short notes and 2 conference papers.

\section{Top 12 Most Productive Countries}

66 countries unevenly participated in global research on COVID-19 vaccine research: 52 countries contribute 1-5 papers each, 7 countries 6-10 papers each, 3 countries each 11-20 and 21-50 papers and 1 countries 110 papers. The $91.25 \%$ share of the global research output and more than $100.0 \%$ share of global citations come from top 12 countries. USA contributed the largest share (32.07\%) to global output, followed by U.K., China and India ( $13.41 \%$ and $11.95 \%$ and $9.04 \%$ respectively), Germany, Italy and Switzerland (from $4.08 \%$ to $4.37 \%$ ) and Canada, South Korea, Australia, France and Russia Federation (from 2.04\% to 2.92\%) during 2020. Of the top 12 countries, only three countries registered relative citation above their group average of 1.15: China (2.27), South Korea (2.11) and USA (1.32). The share of international collaborative papers among top 12 countries varied from $0.00 \%$ to $78.57 \%$, with an average of $51.76 \%$. The share of funded papers in country output varied from $4.76 \%$ to 42.86 (Table 1 ).

\section{Collaborative Linkages among Top 12 Countries}

All the top 12 countries have one to one collaborative linkages, as observed from Table 2 . The top three countries with largest collaborative linkages $(63,41$ and 27$)$ with $10-11$ countries each were depicted by USA, U.K. and Germany. The top three countries with least collaborative linkages (7, 9 and 9) with 4-7 countries were Australia, Canada, South Korea and Russia Federation. Among country-country collaborative linkages, China-U.K. had registered highest number of collaborative linkages (14), followed by USA-U.K., followed by USA-China (13), USAGermany (8 linkages), USA-India and USA-Switzerland (7 linkages each), India-South Korea (6 linkages), U.K.-Germany (5 linkages), etc (Table 2).

\section{Subject-Wise Distribution of Research Output}

Medicine contributed the largest publication share (56.56\%) to global COVID-19 vaccine research, followed distantly by immunology and microbiology (29.15\%), biochemistry, genetics and molecular biology (25.66\%), pharmacology, toxicology and pharmaceutics (13.41\%) and veterinary science (6.71\%) during 2020. Among these 5 subjects, immunology and microbiology registered the highest citation impact per paper (11.69) and veterinary science the least (0.96)( Table 3).

\section{Significant Keywords}

62 important keywords (having more than 18 frequencies and are assumed to be significant) have been identified from the literature on global COVID-19 vaccine research, which through light on the research trends in this research. These keywords are listed in Table 5 in the decreasing order of the frequency of their occurrence in the literature during 2020. The maximum frequency (310) was observed by Virus Vaccine, followed by COVID-19 Vaccine (303), Coronavirus Infection (299), Human (301), Viral Vaccine (299), etc. (Table 4)

\section{Top 17 Most Productive Global Organizations}

159 organizations participated unevenly in global CIOVID-19 vaccine research during 2020: 150 organizations published 1-5 papers each, 8 organizations 6-10 papers each and 1 organization 12 papers. Of the top 17 organizations, 10 are from USA, 4 from China, 2 from U.K. and 1 from India.

The productivity of top 17 most productive organizations varied from 5 to 12 publications per organization; together they contributed $32.07 \%$ (110) global publications share and 52.50\% (1384) global citations share during 2020. The scientometric profile of top 17 most productive organizations having published 5 and more papers is presented in Table 5.

- Six organizations registered their publication output above the group average (6.64) of all organizations: Harvard Medical School, USA (12 papers), University of Washington, Seattle, USA (10 papers), Fudan University, China and University of Oxford, U.K (8 papers each), Baylor College of Medicine, USA and Massachusetts Institute of Technology, USA (7 papers each);

Table 1: Global Publication Output and Share of Top 10 Most Productive Countries in COVID-19 Vaccine Research during 2020.

\begin{tabular}{|c|c|c|c|c|c|c|c|c|c|c|}
\hline S.No & Name of the Country & TP & TC & CPP & ICP & $\%$ ICP & FP & $\% F P$ & $\mathrm{RCI}$ & $\%$ TP \\
\hline 1 & USA & 110 & 1116 & 10.15 & 49 & 44.55 & 31 & 36.9 & 1.32 & 32.07 \\
\hline 2 & U.K. & 46 & 239 & 5.2 & 27 & 58.7 & 15 & 17.86 & 0.68 & 13.41 \\
\hline 3 & China & 41 & 715 & 17.44 & 18 & 43.9 & 21 & 25.00 & 2.27 & 11.95 \\
\hline 4 & India & 31 & 219 & 7.06 & 15 & 48.39 & 8 & 9.52 & 0.92 & 9.04 \\
\hline 5 & Germany & 15 & 73 & 4.87 & 11 & 73.33 & 5 & 5.95 & 0.63 & 4.37 \\
\hline 6 & Italy & 14 & 67 & 4.79 & 4 & 28.57 & 3 & 3.57 & 0.62 & 4.08 \\
\hline 7 & Switzerland & 14 & 42 & 3 & 11 & 78.57 & 5 & 5.95 & 0.39 & 4.08 \\
\hline 8 & Canada & 10 & 54 & 5.4 & 5 & 50 & 5 & 5.95 & 0.7 & 2.92 \\
\hline 9 & South Korea & 9 & 146 & 16.22 & 7 & 77.78 & 4 & 4.76 & 2.11 & 2.62 \\
\hline 10 & Australia & 8 & 11 & 1.38 & 5 & 62.5 & 3 & 3.57 & 0.18 & 2.33 \\
\hline 11 & France & 8 & 47 & 5.88 & 7 & 87.5 & 4 & 4.76 & 0.76 & 2.33 \\
\hline \multirow[t]{4}{*}{12} & Russian Federation & 7 & 37 & 5.29 & 3 & 42.86 & 3 & 42.86 & 0.69 & 2.04 \\
\hline & Total of 12 countries & 313 & 2766 & 8.84 & 162 & 51.76 & 107 & & 1.15 & \\
\hline & Global Total & 343 & 2636 & 7.69 & & & & & & \\
\hline & Share of top 12 in global total & 91.25 & & & & & & & & \\
\hline
\end{tabular}

$\mathrm{TP}=$ Total publications; $\mathrm{TC}=$ Total citations; $\mathrm{CPP}=$ Citations per paper; $\mathrm{ICP}=$ International collaborative papers; $\mathrm{RCI}=$ Relative citation index; $\mathrm{FP}=\mathrm{Funded}$ papers 
Table 2: Collaboration Linkages among Top 12 Countries during 2020.

\begin{tabular}{cccc}
\hline S.No & $\begin{array}{c}\text { Name of } \\
\text { the Country }\end{array}$ & $\begin{array}{c}\text { Number of Collaborative Linkages with } \\
\text { Other Countries }\end{array}$ & TCL(NC) \\
\hline 1 & USA & $2(14), 3(11), 4(7), 5(8), 6(3), 7(7), 8(2)$, & $63(11)$ \\
& & $9(4), 10(2), 11(3), 12(2)$ \\
2 & U.K. & $1(14), 3(3), 4(3), 5(5), 6(1), 7(4), 8(2), 9(3)$, & $41(10)$ \\
& & $10(3), 11(3)$ \\
3 & China & $1(11), 2(3), 4(1), 5(1), 7(2), 8(1), 9(1)$, & $23(10)$ \\
& & $10(1), 11(1), 12(1)$ & \\
4 & India & $1(7), 2(3), 3(1), 5(3), 7(1), 9(6), 11(1), 12(1)$ & $23(8)$ \\
5 & Germany & $1(8), 2(5), 3(1), 4(3), 6(3), 7(1), 8(1), 9(2)$, & $27(10)$ \\
& & $11(2), 12(1)$ & \\
6 & Italy & $1(3), 2(1), 5(3), 7(1), 8(1), 11(1), 12(1)$ & $11(7)$ \\
7 & Switzerland & $1(7), 2(4), 3(2), 4(1), 5(1), 6(1), 8(1), 9(1)$, & $24(11)$ \\
& & $10(1), 11(3), 12(2)$ & \\
8 & Canada & $1(2), 2(2), 3(1), 5(1), 6(1), 7(1), 11(1)$ & $9(7)$ \\
9 & South Korea & $1(4), 2(3), 3(1), 4(6), 5(2), 7(1), 12(1)$ & $18(7)$ \\
10 & Australia & $1(2), 2(3), 3(1), 6(1)$, & $7(4)$ \\
11 & France & $1(3), 2(3), 3(1), 4(1), 5(2), 6(1), 7(3), 8(1)$ & $15(8)$ \\
12 & Russian & $1(2), 3(1), 4(1), 5(1), 6(1), 7(2), 9(1)$ & $9(7)$ \\
& Federation & & \\
\hline
\end{tabular}

${ }^{*} \mathrm{TCL}=$ Total Collaborative linkages; $\mathrm{NC}=$ Number of countries
- Six organizations registered their citation per paper and relative citation index above the group average (12.58 and 1.64) of all organizations: Tongji Medical College, China (56.0 and 7.28), Shanghai Medical College, China (33.2 and 4.32), Chinese Center for Disease Control and Prevention, China (23.5 and 3.06), Fudan University, China (22.88 and 2.97), Massachusetts General Hospital, USA (14.20 and 1.85) and Imperial College London, U.K.( 13.4 and 1.74).

Table 3: Subject-Wise Breakup of Global Publications on COVID-19 Vaccine Analysis Research during 2020.

\begin{tabular}{cccccc}
\hline S.No. & Subject & TP & TC & CPP & \%TP \\
\hline 1 & Medicine & 194 & 1579 & 8.14 & 56.56 \\
2 & $\begin{array}{c}\text { Immunology and } \\
\text { Microbiology }\end{array}$ & 100 & 1169 & 11.69 & 29.15 \\
3 & $\begin{array}{c}\text { Biochemistry, Genetics and } \\
\text { Molecular Biology }\end{array}$ & 88 & 571 & 6.49 & 25.66 \\
4 & $\begin{array}{c}\text { Pharmacology, Toxicology } \\
\text { and Pharmaceutics }\end{array}$ & 46 & 341 & 7.41 & 13.41 \\
5 & Veterinary Science & 23 & 22 & 0.96 & 6.71 \\
& Global total & 343 & 2636 & 7.69 & \\
\hline
\end{tabular}

Table 4: List of Significant Keywords Appearing in Global Publications on COVID-19 Vaccine Research during 2020.

\begin{tabular}{|c|c|c|c|c|c|c|c|c|}
\hline S.No & Name of the Keyword & Frequency & S.No & Name of the Keyword & Frequency & S.No & Name of the Keyword & Frequency \\
\hline 1 & Virus Vaccine & 310 & 23 & Drug Efficacy & 47 & 43 & Biosynthesis & 23 \\
\hline 2 & COVID-19 Vaccine & 303 & 24 & SARS Coronavirus & 47 & 44 & Vaccine Immunogenicity & 23 \\
\hline 3 & Coronavirus Infection & 299 & 25 & $\begin{array}{l}\text { Middle East Respiratory } \\
\text { Syndrome Coronavirus }\end{array}$ & 46 & 45 & Drug Repositioning & 22 \\
\hline 4 & Human & 301 & 26 & Immune Response & 46 & 46 & Virus Genome & 22 \\
\hline 5 & Viral Vaccine & 299 & 27 & Drug Development & 45 & 47 & Passive Immunization & 20 \\
\hline 6 & Pandemic & 289 & 28 & Drug Safety & 45 & 48 & Cellular Immunity & 19 \\
\hline 7 & Virus Pneumonia & 276 & & Virus Antibody & 44 & & Lopinavir Plus Ritonavir & 19 \\
\hline 8 & Coronavirus Disease 2019 & 234 & 29 & $\begin{array}{c}\text { Angiotensin Converting } \\
\text { Enzyme } 2\end{array}$ & 39 & 49 & Epitope & 19 \\
\hline 9 & $\begin{array}{c}\text { Severe Acute Respiratory } \\
\text { Syndrome } 2 \text { Vaccine }\end{array}$ & 189 & 30 & Virus Transmission & 38 & 50 & Favipiravir & 18 \\
\hline 10 & Immunology & 172 & 31 & Drug Design & 38 & 51 & Viral Neutralization & 18 \\
\hline 11 & Non-humans & 143 & 32 & Laboratory Techniques & 33 & 52 & Amino Acid Sequence & 17 \\
\hline 12 & Vaccine & 98 & 33 & Drug Effect & 32 & 53 & Live Vaccine & 16 \\
\hline 13 & Vaccination & 87 & 34 & Remdesivir & 32 & 54 & $\begin{array}{l}\text { Rtidyl-Dipecombinant } \\
\text { Vaccine }\end{array}$ & 16 \\
\hline 14 & Virology & 79 & 35 & SARS Syndrome & 28 & 55 & Messenger RNA & 15 \\
\hline 15 & Genetics & 66 & 36 & Vaccine Production & 28 & 56 & Virus RNA & 14 \\
\hline 16 & $\begin{array}{l}\text { Severe Acute Respiratory } \\
\text { Syndrome (SARS) Vaccine }\end{array}$ & 63 & 37 & Viral Protein & 28 & 57 & RNA Vaccine & 14 \\
\hline 17 & Coronavirus & 60 & 38 & DNA Vaccine & 26 & 58 & Peptidyl-Dipeptidare A & 14 \\
\hline 18 & Clinical Trial & 58 & 39 & Virus Spike Protein & 26 & 59 & Virus Vector & 13 \\
\hline 19 & SARS-COV-2 Spike Protein & 57 & 40 & Chloroquine & 25 & 60 & Adenovirus Vector & 13 \\
\hline 20 & Clinical Trials & 57 & 41 & Hydrochloroquine & 24 & 61 & Epitope & 19 \\
\hline 21 & Neutralizing Antibody & 56 & 42 & Virus Replication & 23 & 62 & Favipiravir & 18 \\
\hline 22 & Anti-Viral Agents & 47 & & & & & & \\
\hline
\end{tabular}


Table 5: Top 17 Most Productive Organizations in COVID-19 Vaccine during 2020.

\begin{tabular}{|c|c|c|c|c|c|c|c|c|}
\hline S.No & Name of the Organization & TP & TC & CPP & $\mathrm{HI}$ & $\mathrm{ICP}$ & ICP (\%) & $\mathrm{RCl}$ \\
\hline 1 & Harvard Medical School, USA & 12 & 138 & 11.50 & 6 & 5 & 41.67 & 1.50 \\
\hline 2 & University of Washington, Seattle, USA & 10 & 27 & 2.70 & 3 & 7 & 70.00 & 0.35 \\
\hline 3 & Fudan University, China & 8 & 183 & 22.88 & 5 & 6 & 75.00 & 2.97 \\
\hline 4 & University of Oxford, U.K. & 8 & 81 & 10.13 & 5 & 4 & 50.00 & 1.32 \\
\hline 5 & Baylor College of Medicine, USA & 7 & 50 & 7.14 & 4 & 1 & 14.29 & 0.93 \\
\hline 6 & Massachusetts Institute of Technology, USA & 7 & 81 & 11.57 & 4 & 2 & 28.57 & 1.50 \\
\hline 7 & John Hopkins University, USA & 6 & 7 & 1.17 & 2 & 4 & 66.67 & 0.15 \\
\hline 8 & National Institute of Health, Bethesda, USA & 6 & 56 & 9.33 & 3 & 3 & 50.00 & 1.21 \\
\hline 9 & Chinese Center for Disease Control and Prevention, China & 6 & 141 & 23.50 & 4 & 1 & 16.67 & 3.06 \\
\hline 10 & Global Healthcare Consulting, India & 5 & 0 & 0.00 & 0 & 0 & 0.00 & 0.00 \\
\hline 11 & Tongji Medical College, China & 5 & 280 & 56.00 & 3 & 1 & 20.00 & 7.28 \\
\hline 12 & Baylor University, USA & 5 & 30 & 6.00 & 2 & 0 & 0.00 & 0.78 \\
\hline 13 & University of Florida, USA & 5 & 5 & 1.00 & 1 & 5 & 100.00 & 0.13 \\
\hline 14 & Imperial College London, U.K. & 5 & 67 & 13.40 & 4 & 4 & 80.00 & 1.74 \\
\hline 15 & Massachusetts General Hospital, USA & 5 & 71 & 14.20 & 3 & 2 & 40.00 & 1.85 \\
\hline 16 & Stanford University, USA & 5 & 1 & 0.20 & 1 & 5 & 100.00 & 0.03 \\
\hline \multirow[t]{4}{*}{17} & Shanghai Medical College, China & 5 & 166 & 33.20 & 3 & 5 & 100.00 & 4.32 \\
\hline & Total of top 17 organizations & 110 & 1384 & 12.58 & 3.12 & 55 & 50.00 & 1.64 \\
\hline & Global total & 343 & 2636 & 7.69 & & & & \\
\hline & Share of Top 17 organizations in global total & 32.07 & 52.50 & & & & & \\
\hline
\end{tabular}

${ }^{*} \mathrm{TP}=$ Total publications; $\mathrm{TC}=$ Total citations; $\mathrm{CPP}=$ Citations per paper; $\mathrm{ICP}=$ International collaborative papers; $\mathrm{RCI}=$ Relative citation index

\section{Institutional Collaboration among Top 15 Organizations}

The total number of collaborative linkages among top 10 organizations is small and varies from 2 to 11 linkages. The top 3 organizations registering highest institutional collaboration linkages were: University of Washington, Seattle, USA, Global Healthcare Consulting, India and Harvard Medical School, USA (11, 7 and 6 linkages with 3-4 organizations. In contrast, the organizations registered the least linkages are: University of Oxford, U.K., Massachusetts Institute of Technology, USA and National Institute of Health, USA (2, 4 and 4 linkages) with 2 organizations each. On individual to individual basis the largest number of collaborative linkages (5) are between University of Washington, Seattle, USA and Global Healthcare Consulting, India, followed by University of Washington, Seattle, USA and National Institute of Health, Bethesda, USA (3 linkages), Harvard Medical School, USA and Massachusetts Institute of Technology, USA (3 linkages), etc. (Table 6).

\section{Top 31 Most Productive Authors}

280 authors unevenly participated in global COVID-10 vaccines research during 2020: 168 authors published 1 papers each, 81 authors 2 papers each, 23 authors 3 papers each, 4 authors 4 papers each, 3 authors 5 papers each and 1 author 6 papers. Of the 31 top authors, 8 each were from USA and India, 7 from U.K., 6 from China, 1 from Russian Federation and 1 not available.

The research productivity of top 31 most productive authors varied from 3 to 6 publications per author. Together they contributed $31.20 \%$ (107) global publications share and $43.74 \%$ (1153) global citations share
Table 6: Collaborative linkages among top 10 organizations in COVID-10 Vaccine Research during 2020.

\begin{tabular}{|c|c|c|c|}
\hline S.No & Name of Organization & $\begin{array}{c}\text { Collaborative } \\
\text { Linkages with } \\
\text { other Organization }\end{array}$ & $\begin{array}{c}\text { Total } \\
\text { Collaborative } \\
\text { Linkages }\end{array}$ \\
\hline 1 & $\begin{array}{c}\text { Harvard Medical School, } \\
\text { USA }\end{array}$ & $2(1), 6(3), 7(2)$ & $6(3)$ \\
\hline 2 & $\begin{array}{c}\text { University of Washington, } \\
\text { Seattle, USA }\end{array}$ & $1(1), 7(2), 8(3), 10(5)$ & $11(4)$ \\
\hline 3 & Fudan University, China & & \\
\hline 4 & University of Oxford, U.K. & $6(1), 8(1)$ & $2(2)$ \\
\hline 5 & $\begin{array}{c}\text { Baylor College of Medicine, } \\
\text { USA }\end{array}$ & & \\
\hline 6 & $\begin{array}{l}\text { Massachusetts Institute of } \\
\text { Technology, USA }\end{array}$ & $1(3), 4(1)$ & $4(2)$ \\
\hline 7 & $\begin{array}{c}\text { John Hopkins University, } \\
\text { USA }\end{array}$ & $1(2), 2(2), 10(1)$ & $5(3)$ \\
\hline 8 & $\begin{array}{l}\text { National Institute of } \\
\text { Health, Bethesda, USA }\end{array}$ & $2(3), 10(1)$ & $4(2)$ \\
\hline 9 & $\begin{array}{c}\text { Chinese Center for Disease } \\
\text { Control and Prevention, } \\
\text { China }\end{array}$ & & \\
\hline 10 & $\begin{array}{l}\text { Global Healthcare } \\
\text { Consulting, India }\end{array}$ & $2(5), 7(1), 8(1)$ & $7(3)$ \\
\hline
\end{tabular}


during 2020. The scientometric profile of top 31 productive authors is presented in Table 7.

- $\quad$ Eight authors registered their publications output above the group average of 3.45: M.E. Bottazzi (Baylor College of Medicine, USA) (6 papers), P.J. Hotez (Baylor College of Medicine, USA), S. Kochhar (Global Healthcare Consultancy, India), C.Qin (Peking Union Medical College, CAS, China) and L.R. Baden (Brighton's and Women's Hospital, Boston, USA)(5 papers each), R.T. Chen (Brighton Collaboration, U.K), S. Morrissey (National Institute of Aging, Baltimore, USA) and E.J. Rubin (Harvard TH Chan School of Public Health, Boston, USA)(4 papers each);
Eight authors registered their citation per paper and relative citation index above the group average (10.78 and 1.40) of all authors: M. Saville (Coalition foe Epidemic Preparedness Innovation, London, U.K (97.0 and 12.61), L. Du (Fudan University, China) (44.0 and 5.72), S. Jiang (Fudan University, China)( 44.0 and 5.72), L. Bao (Harvard Medical School, USA)( 29.0 and 3.77), J. Liu (Chinese Center for Disease Control and Prevention, China)( 29.0 and 3.77), W. Chen (Beijing Institute of Biotechnology, China)( 24.0 and 3.12), C.Qin (Peking Union Medical College, CAS, China)( 18.6 and 2.42) and N. Eyal (Harvard T.H.Chan School of Public Health, USA)( 11.67 and 1.52).

Table 7: Top 31 Most Productive Authors in COVID-19 Vaccine during 2020.

\begin{tabular}{|c|c|c|c|c|c|c|c|c|c|}
\hline S.No & Name of the Author & Affiliation of the Author & TP & $\mathrm{TC}$ & CPP & $\mathrm{HI}$ & ICP & ICP (\%) & $\mathrm{RCl}$ \\
\hline 1 & M.E. Bottazzi & Baylor College of Medicine, USA & 6 & 39 & 6.50 & 3 & 0 & & 0.85 \\
\hline 2 & P.J. Hotez & Baylor College of Medicine, USA & 5 & 39 & 7.80 & 3 & 0 & & 1.01 \\
\hline 3 & S.Kochhar & Global Healthcare Consultancy, India & 5 & 0 & 0.00 & 0 & 0 & 0.00 & 0.00 \\
\hline 4 & C.Qin & Peking Union Medical College, CAS, China & 5 & 93 & 18.60 & 4 & 3 & 60.00 & 2.42 \\
\hline 5 & L.R. Baden & Brighton's and Women's Hospital, Boston, USA & 5 & 0 & 0.00 & 0 & 0 & & 0.00 \\
\hline 6 & R.T. Chen & Brighton Collaboration, U.K. & 4 & 5 & 1.25 & 1 & 4 & 100.00 & 0.16 \\
\hline 7 & S. Morrissey & National Institute of Aging, Baltimore, USA & 4 & 0 & 0.00 & 0 & 0 & & 0.00 \\
\hline 8 & E.J. Rubin & Harvard TH Chan Sch. of Public Health., USA & 4 & 0 & 0.00 & 0 & 0 & & 0.00 \\
\hline 9 & E. Allen & University of Oxford, U.K. & 3 & 22 & 7.33 & 2 & 1 & 33.33 & 0.95 \\
\hline 10 & L. Bao & Harvard Medical School, USA & 3 & 87 & 29.00 & 3 & 1 & 33.33 & 3.77 \\
\hline 11 & S. Belij-Rammerstorfer & University of Oxford, U.K. & 3 & 22 & 7.33 & 2 & 1 & 33.33 & 0.95 \\
\hline 12 & W. Chen & Beijing Institute of Biotechnology, China & 3 & 72 & 24.00 & 2 & 0 & & 3.12 \\
\hline 13 & J. Cohen & Independent Scholar, Russia Federation & 3 & 2 & 0.67 & 1 & 0 & & 0.09 \\
\hline 14 & R.C.Condit & Global Healthcare Consultancy, India & 3 & 0 & 0.00 & 0 & 0 & & 0.00 \\
\hline 15 & D.B. Cory & Baylor College of Medicine, USA & 3 & 30 & 10.00 & 2 & 0 & & 1.30 \\
\hline 16 & L. Du & Fudan University, China & 3 & 132 & 44.00 & 2 & 3 & 100.00 & 5.72 \\
\hline 17 & J.L.Excler & Global Healthcare Consultancy, India & 3 & 0 & 0.00 & 0 & 0 & & 0.00 \\
\hline 18 & N. Eyal & Harvard T.H.Chan School of Public Health, USA & 3 & 35 & 11.67 & 1 & 1 & 33.33 & 1.52 \\
\hline 19 & G.F. Gao & Institute of Microbiology, CAS, China & 3 & 9 & 3.00 & 2 & 1 & 33.33 & 0.39 \\
\hline 20 & C. Gilbride & University of Oxford, U.K. & 3 & 22 & 7.33 & 2 & 1 & 33.33 & 0.95 \\
\hline 21 & M.Guruwith & Global Healthcare Consultancy, India & 3 & 0 & 0.00 & 0 & 0 & & 0.00 \\
\hline 22 & S. Jiang & Fudan University, China & 3 & 132 & 44.00 & 2 & 3 & 100.00 & 5.72 \\
\hline 23 & D. Kim & Global Healthcare Consultancy, India. & 3 & 0 & 0.00 & 0 & 0 & & 0.00 \\
\hline 24 & T. Lambe & University of Oxford, U.K. & 3 & 22 & 7.33 & 2 & 1 & 33.33 & 0.95 \\
\hline 25 & H.Ledford & Not Available & 3 & 12 & 4.00 & 1 & 0 & & 0.52 \\
\hline 26 & J. Liu & $\begin{array}{c}\text { Chinese Center for Disease Control and } \\
\text { Prevention, China }\end{array}$ & 3 & 87 & 29.00 & 3 & 1 & 33.33 & 3.77 \\
\hline 27 & J.Y.Nau & NA & 3 & 0 & 0.00 & 0 & 0 & & 0.00 \\
\hline 28 & J.S.Robertson & Global Healthcare Consultancy, India & 3 & 0 & 0.00 & 0 & 0 & & 0.00 \\
\hline 29 & M. Saville & $\begin{array}{l}\text { Coalition foe Epidemic Preparedness } \\
\text { Innovation, London, U.K. }\end{array}$ & 3 & 291 & 97.00 & 2 & 2 & 66.67 & 12.61 \\
\hline 30 & E.R.Smith & Global Healthcare Consultancy, India & 3 & 0 & 0.00 & 0 & 0 & & 0.00 \\
\hline \multirow[t]{4}{*}{31} & D.Wood & Global Healthcare Consultancy, India & 3 & 0 & 0.00 & 0 & 0 & & 0.00 \\
\hline & & Total of 31 top authors & 107 & 1153 & 10.78 & 1.29 & 23 & 21.50 & 1.40 \\
\hline & & Global total & 343 & 2636 & 7.69 & & & & \\
\hline & & Share of 31 top authors in global total & 31.20 & 43.74 & & & & & \\
\hline
\end{tabular}

${ }^{*} \mathrm{TP}=$ Total publications; $\mathrm{TC}=$ Total citations; $\mathrm{CPP}=$ Citations per paper; $\mathrm{ICP}=$ International collaborative papers; $\mathrm{RCI}=\mathrm{Re}$ lative citation index 


\section{Medium of Research Communication}

Of the total global output on COVID-19 vaccine research, all output (100.0\%) was published in 191 journals. Of the 191 journals which reporting 343 articles, 137 published 1 papers each, 47 published 2-5 papers each, 3 published 6-10 papers each and 4 journals published 12-24 papers during 2020. The top 16 most productive journals accounted for $38.78 \%$ share of total global COVID-19 vaccine research output and $50.27 \%$ share of global citations output in this area that appeared in journal medium during 2020. The top 5 most productive journals were: Nature (24 papers), Science and Vaccine (18 papers each), Lancet (12 papers) and Lancet Infectious Disease (7 papers). The top 5 most impactful journals in terms of citations received were: Journal of Medical Virology (266 citations), Science (212 citations), Cell (136 citations), Lancet (119 citations) and New England Journal of Medicine (117citations). The top 5 journals in terms of citations per paper were: Journal of Medical Virology (66.5), Cell (27.2), New England Journal of Medicine (23.4), Human Vaccine and Immunotherapeutics (19.25) and Nature Communications (18.17) (Table 8).

\section{Highly-Cited Papers}

Of the 343 global publications on COVID-19 vaccine research during 2020, only 15 publications registered 55 to 222 citations per paper (assumed here highly- cited) and they together received a total of 1546 citations, since their publication, averaging to 103.07 citations per paper. The distribution of 15 highly cited papers is highly skewed: 8 papers each were in the range 55-83, 6 papers in citation range 119-182 and 1 paper 222 citations. Among 15 high-cited papers, USA contributed the highest number of papers (6), followed by China (5), South Korea (2), Iran, Netherland, Norway, Taiwan and Thailand (1 paper each). The 15 high cited papers ( 7 articles, 6 reviews and 2 notes) involve 63 organizations

Table 8: Top 10 Most Productive Journals in COVID-19 Vaccine Research during 2020.

\begin{tabular}{|c|c|c|c|c|}
\hline S.No & Name of the Journal & TP & TC & CPP \\
\hline 1 & Nature & 24 & 110 & 4.58 \\
\hline 2 & Science & 18 & 212 & 11.78 \\
\hline 3 & Vaccine & 18 & 17 & 0.94 \\
\hline 4 & Lancet & 12 & 119 & 9.92 \\
\hline 5 & Lancet Infectious Disease & 7 & 13 & 1.86 \\
\hline 6 & Nature Reviews Immunology & 7 & 85 & 12.14 \\
\hline 7 & Nature Communications & 6 & 109 & 18.17 \\
\hline 8 & $\begin{array}{c}\text { American Journal of Tropical } \\
\text { Medicine and Hygiene }\end{array}$ & 5 & 8 & 1.60 \\
\hline 9 & Cell & 5 & 136 & 27.20 \\
\hline 10 & $\begin{array}{l}\text { JAMA Journal of the American } \\
\text { Medical Association }\end{array}$ & 5 & 2 & 0.40 \\
\hline 11 & Journal of Infectious Diseases & 5 & 36 & 7.20 \\
\hline 12 & New England Journal of Medicine & 5 & 117 & 23.40 \\
\hline 13 & BMJ & 4 & 9 & 2.25 \\
\hline 14 & $\begin{array}{l}\text { Human Vaccine and } \\
\text { Immunotherapeutics }\end{array}$ & 4 & 77 & 19.25 \\
\hline 15 & Journal of Medical Virology & 4 & 266 & 66.50 \\
\hline \multirow[t]{4}{*}{16} & Theranostics & 4 & 9 & 2.25 \\
\hline & Total of 16 journal & 133 & 1325 & 9.96 \\
\hline & Global total & 343 & 2636 & 7.69 \\
\hline & Share of 16 journals in global total & 38.78 & 50.27 & \\
\hline
\end{tabular}

and 191 authors. Of the 15 high cited papers, 2 involved zero collaboration, 8 national and 5 international collaboration. In all 13 journals participated in 15 high cited papers. Of these, the largest number of papers (2 each) was published in Journal of Medical Virology and Science, and 1 paper each in Cell, Cellular and Molecular Immunology, Human Vaccines and Immunotherapeutic, Immunity, International Journal of Molecular Science, Journal of Microbiology and Biotechnology, The Lancet, Nature Reviews- Drug Discovery, Nature Reviews-Immunology, New England Journal of Medicine and Viruses. The list of top 10 highcited papers is presented in Table 9.

\section{SUMMARY AND CONCLUSION}

The global COVID-19 vaccine research resulted in 343 publications, which in turn received 2636 citations registering a citation per paper of 7.68. Of the 343 publications, only 84 publications were found to be supported by more 50 funding agencies, which as expected, averaged a much higher average citation per paper of 16.52 citations per paper. Among 66 participating countries in COVID-19 vaccine research, the top 12 countries alone contributed $91.25 \%$ share of the global publication output and above $100.0 \%$ share of global citations received. The largest publication share $(32.07 \%)$ to global output, among top 12 countries, is contributed by USA, followed by U.K., China and India ( $13.41 \%$ and $11.95 \%$ and $9.04 \%$ respectively), Germany, Italy and Switzerland (from $4.08 \%$ to $4.37 \%$ ) etc. The USA and China, being the top most productive country also registered the highest and above average relative citation index (1.32 and 2.27) and share of funded papers (36.90\% and $25.0 \%)$. U.K. and South Korea were also the third most productive and second most impactful country among top 12 countries. USA, U.K. and Germany had made the largest collaborative linkages (63, 41 and 27) amongst top 12 countries, but across countries (14), USA-U.K collaboration seems to be the strongest ( with 14 links)., followed by USA-China (13 links), USA-Germany (8 links), USA-India and USA-Switzerland (7 links), India-South Korea (6 links and U.K.-Germany (5 links). .Among five subjects intersecting with global COVID-19 research, medicine received the highest publication share $(56.56 \%)$ to global COVID-19 vaccine research, followed distantly by immunology and microbiology (29.15\%), biochemistry, genetics and molecular biology (25.66\%), pharmacology, toxicology and pharmaceutics (13.41\%) and veterinary science (6.71\%) during 2020. 159 organizations and 280 authors unevenly participated in global research on COVID-19 vaccine research during 2020, of which the top 17 global most productive organizations and 31 global most productive authors contributed $32.07 \%$ and $31.20 \%$ to global publication share and $52.50 \%$ and $43.74 \%$ global citation share respectively. The five leading organizations in terms of publication productivity were: Harvard Medical School, USA (12 papers), University of Washington, Seattle, USA (10 papers), Fudan University, China and University of Oxford, U.K (8 papers each) and Baylor College of Medicine, USA (7 papers). The five leading organizations in terms of citation impact per paper and relative citation index were: Tongji Medical College, China (56.0 and 7.28), Shanghai Medical College, China (33.2 and 4.32), Chinese Center for Disease Control and Prevention, China (23.5 and 3.06), Fudan University, China (22.88 and 2.97) and Massachusetts General Hospital, USA (14.20 and 1.85). The five leading authors in terms of publication productivity were: M.E. Bottazzi (Baylor College of Medicine, USA)(6 papers), P.J. Hotez (Baylor College of Medicine, USA), S. Kochhar (Global Healthcare Consultancy, India), C. Qin (Peking Union Medical College, CAS, China) and L.R. Baden (Brighton's and Women's Hospital, Boston, USA)(5 papers each). The five leading authors in terms of citation impact per paper and relative citation index were: M. Saville (Coalition foe Epidemic Preparedness Innovation, London, U.K (97.0 and 12.61), L. Du (Fudan University, China)( 44.0 and 5.72), S. Jiang 


\begin{tabular}{|c|c|c|c|c|}
\hline S.No. & Name of the author & Title of the Paper & Source & Times Cited \\
\hline 1 & Wang, Y. et al. & $\begin{array}{l}\text { Unique epidemiological and clinical features of the emerging } \\
2019 \text { novel coronavirus pneumonia (COVID-19) implicate } \\
\text { special control measures (Review) }\end{array}$ & $\begin{array}{l}\text { Journal of Medical Virology 2020, } 92 \\
\text { (6), 568-576. }\end{array}$ & 222 \\
\hline 2 & Thanh Le, T et al. & The COVID-19 vaccine development landscape (Note) & $\begin{array}{l}\text { Nature Reviews. Drug discovery 2020, } \\
\qquad 19 \text { (5), 305-306. }\end{array}$ & 182 \\
\hline 3 & Tai, W. et al. & $\begin{array}{l}\text { Characterization of the receptor-binding domain (RBD) of } 2019 \\
\text { novel coronavirus: implication for development of RBD protein } \\
\text { as a viral attachment inhibitor and vaccine (Article) }\end{array}$ & $\begin{array}{l}\text { Cellular and Molecular Immunology } \\
2020,17(6), 613-620 .\end{array}$ & 135 \\
\hline 4 & Grifoni, A. et al. & $\begin{array}{l}\text { Targets of T Cell Responses to SARS-CoV-2 Coronavirus in } \\
\text { Humans with COVID-19 Disease and Unexposed Individuals } \\
\text { (Article) }\end{array}$ & Cell 2020, 181 (7), 1489-1501.e15. & 129 \\
\hline 5 & Amanat, F. and Krammer, F. & SARS-CoV-2 Vaccines: Status Report (Review) & Immunity, 2020, 52 (4), 583-589 & 126 \\
\hline 6 & Lurie, N. et al. & Developing covid-19 vaccines at pandemic speed (Review) & $\begin{array}{l}\text { New England Journal of Medicine 2020, } \\
\qquad 382(21), 1969-1973\end{array}$ & 121 \\
\hline 7 & Jin, Y. et al. & $\begin{array}{c}\text { Virology, epidemiology, pathogenesis, and control of covid-19 } \\
\text { (Review) }\end{array}$ & Viruses 2020, 12 (4), art. no. 372 , & 119 \\
\hline 8 & Ahn, D.G et al. & $\begin{array}{l}\text { Current status of epidemiology, diagnosis, therapeutics, and } \\
\text { vaccines for novel coronavirus disease } 2019 \text { (COVID-19) } \\
\text { (Review). }\end{array}$ & $\begin{array}{l}\text { Journal of Microbiology and } \\
\text { Biotechnology, } 30 \text { (3), 313-324 }\end{array}$ & 83 \\
\hline 9 & Dharma, K. et al. & $\begin{array}{l}\text { COVID-19, an emerging coronavirus infection: advances } \\
\text { and prospects in designing and developing vaccines, } \\
\text { immunotherapeutics, and therapeutics (Review). }\end{array}$ & $\begin{array}{c}\text { Human Vaccines and } \\
\text { Immunotherapeutics 2020, } 16 \text { (6), } \\
1232-1238\end{array}$ & 69 \\
\hline 10 & Gao, Q. et al. & $\begin{array}{l}\text { Development of an inactivated vaccine candidate for SARS- } \\
\qquad \text { CoV-2 (Article) }\end{array}$ & Science 2020,369 (6499), 77-81 & 68 \\
\hline
\end{tabular}

(Fudan University, China)( 44.0 and 5.72), L. Bao (Harvard Medical School, USA)( 29.0 and 3.77) and, J. Liu (Chinese Center for Disease Control and Prevention, China)( 29.0 and 3.77).

The journals medium (343 papers) accounted for $100.0 \%$ share of global publications on COVID-19 vaccine research and witnessed the participation of 280 journals. The top 16 journals alone accounts for $38.78 \%$ share and $50.27 \%$ share respectively of global COVID-19 vaccine research output and citations during 2020. The serial publication Nature contributed the largest number of papers (24) among top 16, followed by Science and Vaccine (18 papers each), The Lancet (12 papers) and The Lancet Infectious Disease (7 papers). The serial Journal of Medical Virology registered the highest number of citations (266) among top 16, followed by Science (212 citations), Cell (136 citations), The Lancet (119 citations) and New England Journal of Medicine (117citations). The serial Journal of Medical Virology also received the top slot in citations impact per paper (66.5), followed by Cell (27.2), New England Journal of Medicine (23.4), Human Vaccine and Immunotherapeutics (19.25) and (18.17). From the above it is observed that all leading journals constitute high- impact journals and they took lead in highlighted various issues of COVID-19 vaccine research and they gave top priority in publishing such research, besides providing free access to global community. Only 15 out of 343 global publications on COVID-19 vaccine research during 2020 received 1546 citations (ranging from 55 to 222 citations per paper), averaging 103.07 citations per paper. USA contributed the highest number of papers (6), followed by China (5), etc. These 15 high-cited papers were published in 13 journals, with 2 papers published each in Journal of Medical Virology and Science and 1 paper each in 11 other journals.

Conclude that currently there is no vaccine to prevent COVID -19 and the analysis presented in this paper hopes to provide useful information on the present status and future directions for COVID-19 vaccine research which can be utilized by policy-makers in improving the research in their countries. We hope that vaccine for COVID-19 will be available within the next few months.

\section{CONFLICT OF INTEREST}

The authors declare that there is no conflict of interest.

\section{REFERENCES}

1. Holmes, K.K, Bertozzi, S, Bloom, B. R, et al. editors. Chapter 1. Major infectious diseases: Key messages from disease control priorities, 3rd Edition. In Major Infectious Diseases. 3rd edition. Washington, DC: IBRD/The World Bank; 2017 https://www.ncbi.nlm.nih.gov/books/NBK525197/doi: 10.1596/978-1-46480524-0_ch1

2. Ram, Shri. Coronavirus research trends: A 50-year bibliometric assessment. Science and Technology Libraries 2020, 39(2), 210-226, DOI: 10.1080/0194262X.2020.1742270

3. Wang, C, Horby, P.W, Hayden, F.G, et al. A novel coronavirus outbreak of global health concern. Lancet 2020, 395, 470-473.

4. WHO Coronavirus Disease (COVID-19) Dashboard. Data last updated: 16.9.2020. https://covid19.who.int/ (Accessed on 18 September 2020)

5. Gorbalenya, A.E., Baker, S.C., Baric, R.S. et al. The species severe acute respiratory syndrome-related coronavirus: classifying 2019-nCoV and naming it SARS-CoV-2. Nat Microbiol 2020, 5, 536-544. https://doi.org/10.1038/s41564020-0695-Z

6. Adhikari, S.P, Meng, S, Wu, Y.J, Mao, Y.P, Ye, R.X, Wang, Q. Z, Sun, C, Sylvia, S, Rozelle, S, Raat, H, et al. Epidemiology, causes, clinical manifestation and diagnosis, prevention and control of coronavirus disease (COVID-19) during the early outbreak period: a scoping review. Infect Dis Poverty. 2020,9(1), 29.

7. Fan, Jingchun, Gao, Ya, Zhao, Na, Dai, Runjing, Zhang, Hailiang, Feng, Xiaoyan, Shi, Guoxiu, Tian, Jinhui, Chen, Che, Hambly, Brett D. and Bao, Shisan. Bibliometric analysis on COVID-19: A comparison of research between English and Chinese Studies. Frontiers in Public Health 2020, 8, 477PP. https://www.frontiersin.org/ article/10.3389/fpubh.2020.00477. DOI=10.3389/fpubh.2020.00477

8. WHO. Accelerating a safe and effective COVID-19 vaccine. 2020. https://www. who.int/emergencies/diseases/novel-coronavirus-2019/global-research-onnovel-coronavirus-2019-ncov/accelerating-a-safe-and-effective-covid-19-vaccine (Accessed on 18 September 2020).

9. WHO. Draft landscape of COVID-19 candidate vaccines. 9 September 2020 https://www.who.int/publications/m/item/draft-landscape-of-covid-19-candidate-vaccines 
10. Le, Tung Thanh; Cramer, Jakob P.; Chen, Robert; Mayhew, Stephen (4 September 2020). Evolution of the COVID-19 vaccine development landscape. Nat Rev Drug Discov . 2020;19(10):667-8. DOI: 10.1038/d41573-020-00151

11. COVID-19 vaccine development pipeline. Vaccine Centre, London School of Hygiene and Tropical Medicine. 1 September 2020. Retrieved 3 September 2020.

12. COVID-19 vaccine tracker. Milken Institute. 2 September 2020. Retrieved 2 September 2020. (Accessed on 10 September 2020).

13. WHO. Draft landscape of COVID 19 candidate vaccines. 3 September 2020. Retrieved 3 September 2020.

14. COVID-19 vaccine. 14 September 2020. https://en.wikipedia.org/wiki/ COVID-19_vaccine (Accessed on 18 September 2020)

15. Joshua V and Sivaprakasam S. Coronavirus: Bibliometric analysis of scientific publications from 1968 to 2020. Med J Islam Repub Iran. 2020; 34 (1) :456-463. URL: http://mjiri.iums.ac.ir/article-1-6715-en.html
16. Zyoud, S.H. and Al-Jabi, S.W. Mapping the situation of research on coronavirus disease-19 (COVID-19): a preliminary bibliometric analysis during the early stage of the outbreak. BMC Infect Dis 20. 561 (2020). https://doi.org/10.1186/ s12879-020-05293-z

17. Lou, J , Tian, SJ., Niu, SM, Kang, XQ, Lina, HX, Zhang, LX and Zhang, JJ. Coronavirus disease 2019: a bibliometric analysis andreview. Eur Rev Med Pharmacol Sci 2020, 24(6), 3411-3421. DOI: 10.26355/eurrev_202003_20712

18. Felice, Francesca De and Polimeni, Antonella. Review: Coronavirus Disease (COVID-19): A machine learning bibliometric analysis. In vivo June 202034 (3 SuppL) 1613-1617; doi:10.21873/invivo.11951

19. Gupta BM, Dhawan SM, Ahmed KKM, Mamdapur GM. Global research on COVID-19 disease: A scientific assessment of publications during 2020-21. Int J Med Public Health. 2021;11(2):76-84

Article History: Received: 31-08-2020; Revised: 02-11-2020; Accepted: 13-03-2021

Cite this article: BM Gupta, Ahmed KKM. COVID-2019 Vaccine: A Scientometric Assessment of Global Publications during 2020. J Young Pharm. 2022;14(1):37-45. 